\title{
Pengaruh Penerapan Model Penemuan Terbimbing Berbantuan Power Point terhadap Hasil Belajar Materi Trigonometri Siswa Kelas X
}

\author{
Bayu Setiawan $^{1}$ \\ ${ }^{1}$ Institut Agama Islam Negeri Tulungagung \\ Email: ${ }^{1}$ bayu.stn.1@gmail.com
}

\section{Tersedia Online di \\ http://www.jurnal.unublitar.ac.id/ index.php/briliant}

\begin{tabular}{l}
\hline Sejarah Artikel \\
\hline Diterima pada 5 November 2017 \\
Disetuji pada 5 November 2017 \\
Dipublikasikan pada 13 \\
November 2017 Hal. $504-511$ \\
\hline
\end{tabular}

\section{Kata Kunci:}

Penemuan terbimbing, hasil belajar

\section{DOI:}

http://dx.doi.org/10.28926/briliant .v2i4.112

\begin{abstract}
Abstrak: Permasalahan pembelajaran di kelas dapat diatasi dengan desain pembelajaran yang merangsang siswa untuk belajar mandiri, lebih aktif, dan kreatif sesuai dengan kenyamanan siswa dalam belajar dan dibantu dengan kemapuan teknologi. Tujuan dari penelitian ini adalah untuk mengetahui ada tidaknya dan besar pengaruh model pembelajaran penemuan terbimbing (guided discovery) berbantuan powerpoint terhadap hasil belajar matematika siswa materi trigonometri kelas $X$. Penelitian ini menggunakan pendekatan kuantitatif dengan jenis penelitian eksperimen semu. Hasil penelitian disimpulkan bahwa, ada pengaruh positif dan signifikan model pembelajaran penemuan terbimbing (guided discovery) berbantuan powerpoint terhadap hasil belajar matematika materi trigonometri siswa kelas X MIA MAN Kota Blitar dengan kategori sedang yaitu $76 \%$.
\end{abstract}

Pendidikan merupakan hal yang melekat pada diri manusia, mulai dari lahir sampai tua setiap manusia pasti melaksanakan pendidikan. Oleh sebab itu, pendidikan sangat menenentukan peradaban budaya dan segala sesuatu dalam kehidupan manusia. Karena pendidikan adalah segala pengalaman belajar yang berlangsung dalam segala lingkungan dan sepanjang hidup (Maunah, 2009:1).

Pendidikan Nasional bertujuan untuk mengembangkan potensi peserta didik agar menjadi manusia yang beriman dan bertakwa kepada Tuhan Yang Maha Esa, berakhlak mulia, sehat, berilmu, cakap, kreatif, mandiri, dan menjadi warga negara yang demokratis serta bertanggung jawab. Tujuan pendidikan sangatlah penting dalam mendorong kemajuan peradaban, terutama sekarang ini pada abad modern yang segala sesuatunya serba teknologi. Dalam Al-Quran Surat Al Hijr ayat 29 manusia sudah dilengkapi dengan beragai potensi yang dapat dikembangkan antara lain berupa fitrah ketuhidan.

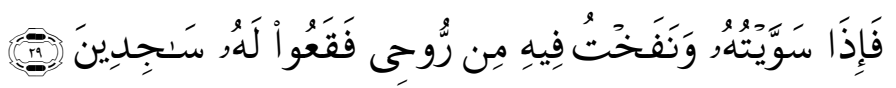

Artinya: Maka apabila aku telah menyempurnakan kejadiannya, dan telah meniup kan kedalamnya ruh (ciptaan)-Ku, Maka tunduklah kamu kepadanya dengan bersujud (Tim Penyusun, 2006:263).

Dengan fitrah ini diharapkan manusia dapat hidup sesuai dengan hakekat penciptanya, yaitu mengabdi kepada Allah SWT. sebagai penciptanya sesuai ayat dalam Al-Quran surat Adz-Zariyaat ayat 56. 


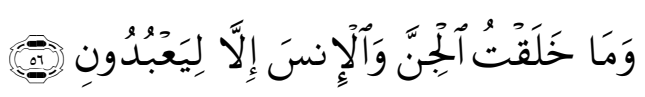

Artinya: Dan aku tidak menciptakan jin dan manusia melainkan supaya mereka mengabdi kepada-Ku.

Sejalan dengan kepentingan itu maka kepada manusia dianugrahkan oleh penciptanya berbagai potensi yang dapat dikembangkan melalui pendidikan yang terarah, teratur dan berkesinambungan (Pidarta, 1997:523).

Untuk mewujudkan tujuan pendidikan yang dimuat dalam Peraturan Pemerintahan RI Nomor 17 Tahun 2010 pasal 77, berbunyi: "Pendidikan menengah bertujuan membentuk peserta didik menjadi insan yang beriman dan bertakwa kepada Tuhan Yang Maha Esa, berahklah mulia, dan berkepribadian luhur, berilmu, cakap, kritis, kreatif, inovatif, sehat, mandiri, percaya diri, toleran, peka sosial, demokratis, dan bertanggung jawab. Oleh karena itu dalam lembaga formal perlu adanya kurikulum pendidikan untuk mewujudkan tujuan pendidikan.

Pemerintah mengembangkan kurikulum pendidikan yang ada di sekolah formal mulai dari kurikulum Rencana Pelajaran (1947-1968), kurikulum Berbasis Tujuan (1975-1984), kurikulum KBK dan KTSP (2004-2006), sampai kurikulum yang terbaru saat ini yaitu kurikulum 2013 atau yang lebih dikenal kurikulum K13. Kurikulum 2013 merupakan Kurikulum Tingkat Satuan Pendidikan (KTSP) yang berfokus pada penguasaan pengetahuan yang kontekstual sesuai daerah dan lingkungan masing-masing. Kurikulum tersebut menitikberatkan penilaian siswa pada tiga hal: sikap, keterampilan (melalui tugas praktek/ proyek sekolah), dan pengetahuan.

Penerapan kurikulum 2013 terutama pada mata pelajaran matematika cukup sulit, dikarenakan dalam pelaksanakannya perlu persiapan yang matang. Kebanyakan pada saat ini kesulitan timbul dari siswa itu sendiri. Hasil dari pengamatan dua sekolah di Blitar banyak siswa yang mengeluhkan tentang pelajaran matematika. Dalam hal ini karena matematika yang dianggap sulit dipahami dan siswa belum begitu memahami kegunaannya dalam kehidupan sehari-hari. Kenyataan yang dapat dilihat bahwa dalam hasil belajar matematika yang dicapai siswa masih rendah. Hasil belajar adalah kemampuan yang diperoleh anak setelah melalui kegiatan belajar (Susanto, 2013:5). Hasil belajar dapat dilihat dengan melaksanakan evaluasi atau penialaian yang selanjutnya sebagai dasar tindak lanjut pembelajaran dan untuk mengukur kemampuan siswa. Penilaian hasil belajar mencakup segala hal yag dipelajari disekolah. Macam-macam hasil belajar meliputi pemahaman konsep, ketrampilan proses, dan sikap siswa (Susanto, 2013:6). Tugas guru untuk mendesain pembelajaran dikelas yang menarik, sehingga tujuan pembelajaran dan proses memaknai belajar oleh siswa bisa tercapai.

Salah satu materi yang dianggap sulit yaitu trigonometri. Banyak siswa belum mengetahui manfaat dari mempelajari materi trigonometri, sehingga siswa kurang tertarik memepelajarinya. Siswa juga menganggap trigonometri materi yang hanya membahas sin, cos, dan tan, hal tersebut sulit dipahami siswa. Oleh sebab itu guru mempunyai tugas yang berat untuk merubah pandangan siswa tentang hal tersebut dan menciptakan suasana pemebelajaran yang menarik.

Pada pelaksanaan pembelajaran di kelas guru harus mampu memilih metode pembelajaran yang tepat karena cara guru dalam menyampaikan materi pelajaran sangat mempengaruhi kelancaran proses pembelajaran dan minat siswa terhadap

505 BRILIANT: Jurnal Riset dan Konseptual Volume 2 Nomor 4, November 2017 
materi pelajaran yang pada akhirnya akan berpengaruh terhadap prestasi belajar siswa. Bahan menyatakan bahwa guru berkewajiban untuk mencapai kegiatan pembelajaran yang mampu mengembangkan kemampuan kognitif, psikomotorik dan afektif bagi siswa agar mencapai hasil pembelajaran yang optimal (Dimyati \& Mudjiono, 2002:4).

Melihat kondisi tersebut, maka seorang guru kreatif dapat meningkatkan hasil belajar siswa dengan model pembelajaran yang kreatif dan menarik. Dalam hal ini teknologi juga mempunyai peran yang besar dalam mendesain pembelajaran yang lebih menarik. Banyak aplikasi berbasis windows saat ini beredar dalam menunjang pembelajaran matematika salah satunya yaitu aplikasi Microsoft PowerPoint. Microsoft PowerPoint merupakan aplikasi berbasis windows yang dikeluarkan oleh perusahaan Microsoft Office. Aplikasi ini memiliki banyak kelebihan terutam mempermudah guru dalam menerangkan materi berupa ilustrasi berupa gambar, video, suara dan lain sebagainya. Microsoft PowerPoint juga mudah dibuat karena fitur-fitur dalam membuat presentasi sudah tersedia di aplikasi tersebut. Hal ini dapat diterapkan dengan memberikan file aplikasi ini kepada siswa, sehingga siswa dapat belajar secara mandiri guru.

Hasil pengamatan peneliti di tempat peneliti melaksanakan Praktik Pengalaman Lapangan, mayoritas pembelajaran matematika dilaksanakan dengan cara konvensional sehingga siswa kurang aktif dalam pembelajaran. Oleh sebab itu dalam kajian penelitian ini peneliti akan menggunakan model penemuan terbimbing (guided discovery).

Model penemuan terbimbing adalah model pembelajaran yang mendorong peserta didik untuk mengidentifikasi apa yang ingin diketahui dilanjutkan dengan mencari informasi sendiri kemudian mengorganisasi atau membentuk (konstruktif) apa yang mereka ketahui dan mereka pahami (Kementerian Pendidikan dan Kebudayaan, 2014:37). Sehingga guru sebagai pembimbing dan atau mengarahakan siswa, sedangkan siswa dituntut aktif dan partisipatif dalam proses belajar mengajar dikelas. Melihat latar belakang tersebut tujuan penelitian ini adalah adalah untuk mengetahui ada tidaknya dan besar pengaruh model pembelajaran penemuan terbimbing (guided discovery) berbantuan powerpoint terhadap hasil belajar matematika siswa materi trigonometri kelas X MIA.

\section{METODE}

Pendekatan yang digunakan dalam penelitian ini adalah pendekatan kuantitatif. Variabel yang diamati ada dua yaitu penemuan terbimbing (guided discovery) berbantuan powerpoint sebagai variabel bebas dan hasil belajar sebagai variabel terikat. Jenis penelitian yang digunakan adalah quasy experiment atau eksperimen semu. Peneliti secara sengaja menimbulkan, menciptakan dan mengkondisikan suatu kejadian atau keadaan yang kemudian diteliti akibat dari perlakuan tersebut.

Populasi penelitian ini adalah kelas X MIA yang berjumlah 4 kelas. Menggunakan teknik random sampling terpilih 2 kelas yaitu kelas X MIA 2 sebagai kelas kontrol dan X MIA 4 sebagai kelas eksperimen. Kelas eksperimen merupakan kelas yang diberi model pembelajaran penemuan terbimbing (guided discovery) berbantuan powerpoint dan kelas kontrol menggunakan model pembelajaran konvesional dengan buku siswa. Sehingga, peneliti bias mengetahui 
ada tidaknya pengaruh dan seberapa besar pengaruh penerapan model pembelajaran penemuan terbimbing (guided discovery) terhadap hasil belajar siswa.

Instrumen yang dipakai adalah tes. Tes berisi 5 butir soal yang diberikan kepada siswa diakhir pembelajaran untuk mengetahui sejauh mana pemahaman siswa dan hasil belajar siswa. Teknik analisis data yang digunakan dalam penelitian ini ada dua tahap yaitu tahap pertama uji prasyarat dengan menggunakan uji homogenitas dan normalitas dan tahap ke dua uji hipotesis menggunakan analisis uji beda (t-test).

\section{HASIL}

Analisis validitas instrumen tes berupa 5 item soal yang diujikan dilapangan. Dari perhitungan menggunakan SPSS diperoleh nilai $r_{\text {hitung }}$ soal nomor 1 adalah 0.493 , soal nomor 2 adalah 0.448 , soal nomor 3 adalah 0.657 , soal nomor 4 adalah 0.642 , dan soal nomor 5 adalah 0.546. Semua item soal menghasilkan nilai $r_{\text {hitung }}>r_{\text {tabel }}$ dengan $N=24$ dan taraf signifikasi $5 \%$ yaitu $r_{\text {tabel }}=0.404$ sehingga semua item valid. Anlisis reliabilitas tes, berdasarkan perhitungan dengan SPSS diperoleh 0.444 dan $r_{\text {tabel }}$ dicari pada taraf signifikasi $5 \%$ dengan $N=24 . \quad \mathrm{Dk}=24-1=23$ diperoleh $r_{\text {tabel }} 0.413$ oleh karena $r_{\text {hitung }}>r_{\text {tabel }}$ atau $0.444>0.413$ maka dapat disimpulkan bahwa item-item instrumen penelitian tersebut dinyatakan reliabel.

Hasil perhitungan homogenitas dari nilai raport kelas eksperimen dan kelas kontrol menunjukkan signifikasi 0.266 yang berarti $>0,05$ sehingga data homogen. Adapun hasil uji normalitas nilai post-test menggunkan uji Kolmogorov-Smirnov diperoleh bahwa data rat-rata berdistribusi normal jika memiliki Asymp Sig. (2-tailed) >0,05. Dari hasil uji diperoleh nilai Asymp Sig. (2-tailed) $=0.14$ pada kelas eksperimen dan 0.28 pada kelas kontrol menunjukkan nilai Asymp Sig. (2-tailed) $>0,05$ ini berarti data di atas berdistribusi normal pada taraf signifikansi 0,05 .

Nilai post-test selanjutnya dianalisis dengan uji-t terhadap untuk mengetahui adakah perbedaan hasil belajar matematika antara kelas eksperimen dan kelas kontrol dan untuk mengetahui ada pengaruh atau tidak pembelajaran penemuan terbimbing berbantuan powerpoint terhadap hasil belajar. Dari perhitungan manual, diperoleh $t_{\text {hitung }}=3,25$. $\mathrm{Db}=78-2=76$ pada taraf signifikansi 0,05 nilai $t_{\text {tabel }}=2.000$. Karena $t_{\text {hitung }}>t_{\text {tabel }}$ maka $\mathrm{H}_{0}$ ditolak dan $\mathrm{H}_{1}$ diterima yang artinya ada pengaruh model pembelajaran penemuan terbimbing (guided discovery) berbantuan powerpoint terhadap hasil belajar matematika materi trigonometri siswa kelas X MIA MAN Kota Blitar.

Group Statistics

Tabel 1 Hasil Uji t-test

\begin{tabular}{|l|l|l|l|l|l|}
\hline & Kelas & $\mathrm{N}$ & Mean & $\begin{array}{l}\text { Std. } \\
\text { Deviation }\end{array}$ & Std. Error Mean \\
\hline Nilai kelas eksperimen & 41 & 87.59 & 12.243 & 1.912
\end{tabular}




\begin{tabular}{|l|l|l|l|l|}
\hline kelas control & 37 & 77.84 & 14.098 & 2.318 \\
\hline
\end{tabular}

Independent Samples Test

\begin{tabular}{|c|c|c|c|c|c|c|c|c|c|c|}
\hline & \multicolumn{2}{|c|}{$\begin{array}{l}\text { Levene's } \\
\text { Test for } \\
\text { Equality of } \\
\text { Variances }\end{array}$} & \multicolumn{7}{|c|}{ t-test for Equality of Means } \\
\hline & & \multirow[b]{2}{*}{$\mathrm{F}$} & \multirow[b]{2}{*}{ Sig. } & \multirow[b]{2}{*}{$\mathrm{T}$} & \multirow[b]{2}{*}{$\mathrm{df}$} & \multirow{2}{*}{$\begin{array}{l}\text { Sig. } \\
(2- \\
\text { tailed) }\end{array}$} & \multirow{2}{*}{$\begin{array}{l}\text { Mean } \\
\text { Differ } \\
\text { ence }\end{array}$} & \multirow{2}{*}{$\begin{array}{l}\text { Std. } \\
\text { Error } \\
\text { Differen } \\
\text { ce }\end{array}$} & \multicolumn{2}{|c|}{$\begin{array}{l}95 \% \\
\text { Confidence } \\
\text { Interval of the } \\
\text { Difference }\end{array}$} \\
\hline & & & & & & & & & $\begin{array}{l}\text { Low } \\
\text { er }\end{array}$ & Upper \\
\hline \multirow[t]{2}{*}{ Nilai } & $\begin{array}{l}\text { Equal } \\
\text { variances } \\
\text { assumes }\end{array}$ & .157 & $\begin{array}{l}.69 \\
3\end{array}$ & $\begin{array}{l}3.26 \\
8\end{array}$ & 76 & .002 & 9.748 & 2.983 & $\begin{array}{l}3.80 \\
7\end{array}$ & 15.68 \\
\hline & $\begin{array}{l}\text { Equal } \\
\text { variances } \\
\text { not } \\
\text { assumes }\end{array}$ & & & $\begin{array}{l}3.24 \\
4\end{array}$ & $\begin{array}{l}71.76 \\
2\end{array}$ & .002 & 9.748 & 3.005 & $\begin{array}{l}3.75 \\
8\end{array}$ & 15.73 \\
\hline
\end{tabular}

Dari perhitungan menggunakan SPSS juga diperoleh data pada kelas eksperimen dengan jumlah rsponden 41 siswa memiliki mean (rata-rata) 87.59 Sedangkan pada kelas kontrol memiliki rata-rata 77.84 dengan jumlah responden 37 siswa dan nilai t_hitung=3.268. Dapat dilihat nilai signifikansi t_hitung=3.268 dengan Sig.(2-tailed) 0.002. Karena jumlah sampel yang diteliti adalah siswa, maka $\mathrm{db}=78-2=76$. Nilai $\mathrm{db}=76$ pada taraf signifikansi $5 \%$ diperoleh t_tabel=2.000. karena t_hitung $>$ t_tabel atau 3.268 $>2.000$ dan Sig.(2-tailed) = $0.002<0.05$. maka H_0 ditolak dan H_1 diterima. Jadi dapat disimpulkan Ada pengaruh model pembelajaran penemuan terbimbing (guided discovery) berbantuan powerpoint terhadap hasil belajar matematika materi trigonometri siswa kelas X MIA MAN Kota Blitar.

Perhitungan effect size digunakan untuk mengetahui besar pengaruh model pembelajran penemuan terbimbing (guided discovery) berbantuan powerpoint terhadap hasil belajar matematika. Berdasarkan perhitungan effect size pada Uji-t digunakan rumus Cohen's, dapat disimpulkan bahwa besarnya pengaruh model pembelajaran penemuan terbimbing terhadap hasil belajar matematika materi trigonometri siswa kelas X MIA MAN Kota Blitar adalah sebesar 0,76 dan dalam tabel interpretasi nilai Cohen's adalah $76 \%$ yang tergolong sedang

\section{PEMBAHASAN}

Berdasarkan penelitian yang telah dilakukan, dari nilai post-test pada kelas eksperimen (X MIA 4), yaitu kelas dengan menerapkan model pembelajaran penemuan terbimbing (guided discovery), dan kelas kontrol (X MIA 2) dengan menggunakan model pembelajaran konvensional. Diketahui bahwa rata-rata hasil belajar matematika materi trigonometri dengan menggunakan model pembelajaran penemuan terbimbing (guided discovery) adalah 87,59. Sedangkan pada kelas 
kontrol, nilai rata-rata hasil belajar matematika materi trigonometri adalah 77,84. Kriteria Ketuntasan Minimum (KKM) untuk bidang studi matematika adalah 72, berdasarkan KKM rata-rata hasil belajar kelas eksperimen dan kontrol sudah melebihi KKM yang berarti materi trigonometri sudah dapat dikatakan berhasil dikuasai oleh siswa.

Berdasarkan pedoman penilaian, rata-rata hasil belajar kelas eksperimen yaitu 87,59 tergolong sangat baik, sedangkan kelas kontrol dengan hasil belajar yaitu 77,84 tergolong baik. Rata-rata nilai kelas eksperimen jauh lebih baik dari pada rata-rata nilai kelas kontrol atau dapat dikatakan bahwa hasil belajar kelas eksperimen lebih baik dari hasil belajar kelas kontrol. Faktor yang mempengaruhi hasil belajar pada kelas eksperimen adalah model pembelajaran yang digunakan. Kelas ekperimen menggunakan model pembelajaran penemuan terbimbing (guided discovery) dengan berbantuan powerpoint, sedangkan kelas kontrol tetap menggunakan model pembelajaran konvensional

Berdasarkan analisis data, penerapan model pembelajaran penemuan terbimbing memberikan pengaruh positif dan signifikan terhadap hasil belajar siswa pada materi trigonometri siswa kelas X MIA MAN Kota Blitar. Hal ini ditunjukkan oleh nilai $t_{\text {hitung }}>t_{\text {tabel }}$ atau 3,268 $>2,000$ pada taraf signifikansi 5\%.

Hasil penelitian ini menunjukkan bahwa model pembelajaran penemuan terbimbing (guided discovery) lebih baik dalam meningkatkan hasil belajar siswa dari pada model pembelajaran konvensional. Dengan menggunakan model pembelajaran penemuan terbimbing (guided discovery), siswa pada kelas eksperimen menjadi lebih aktif, interaksi dengan teman sekelompok juga sangat baik. Dalam proses penemuan atau membuat konjektur (prakiraan), mereka sangat aktif bertanya, sehingga mereka bisa mengkonstruksi sendiri konsep trigonometri. Hasil belajar pada kelas eksperimen juga lebih baik dari pada hasil belajar kelas kontrol, sehingga dapat dikatakan model pembelajaran penemuan terbimbing (guided discovery) dapat meningkatkan ketrampilan dan proses kognitif.

Selain itu penggunaan powerpoint dalam proses pembelajaran mempunyai nilai praktis dan dapat membangkitkan minat belajar siswa dan merangsang siswa untuk belajar. Powerpoint bisa didesain semenarik mungkin, sehingga siswa mempunyai minat yang tinggi terhadap matematika dalam mengikuti pembelajaran.

Berdasarkan analisis data hasil penelitian diatas, menunjukkan hasil yang positif dan signifikan. Hal ini disebabkan karena dengan menggunakan model pembelajaran penemuan terbimbing (guided discovery), siswa yang berperan aktif dalam proses pembelajaran. Siswa diarahkan oleh guru yang bertindak sebagai fasilitator agar bisa memperoleh pengalaman dalam menemukan sendiri konsep yang direncanakan guru menggunakan powerpoint, siswa dituntut untuk selalu aktif dalam proses pembelajaran dengan berusaha sendiri untuk mencari pemecahan masalah, dan siswa dapat memahami konsep pembelajaran sesuai dengan versi mereka sendiri, sehingga menghasilkan pengetahuan yang benarbenar bermakna.

Penggunaan model pembelajaran penemuan terbimbing memberikan dampak positif bagi siswa, khususnya dalam meningkatkan hasil belajar siswa. Menurut Gagne hasil belajar antara lain: a) informasi verbal adalah kapabilitas mengungkapkan pengetahuan dalam bentuk bahas, baik lisan maupun tertulis; b) ketrampilan intelektual adalah kemampuan mempresentasikan konsep dan 
lambang. Hal ini sangat sesuai dengan penerapan model penemuan terbimbing (guided discovery), yaitu model ini mengarahkan siswa untuk membuat konjektur (prakiraan) sebagai media awal siswa mengungkapkan pemahaman awal dari apa yang mereka pelajari dan selanjutnya ke tahap verbalisasi yang dilakukan sendiri oleh siswa dengan bimbingan dari guru tentang konsep yang ditemukan; c) ketrampilan motorik adalah kemampuan melakukan serangkaian gerakan jasmani dalam urusan dan koordinasi sehingga terwujud otomatisme gerak jasmani. Hal tersebut juga sesuai dengan penerapan model penemuan terbimbing (guided discovery) yaitu model ini menuntut siswa lebih aktif melakukan diskusi dengan kelompok dan aktif bertanya kepada guru.

Dari uraian diatas dapat diketahui bahwa penerapan model penemuan terbimbing (guided discovery) berpengaruh positif dalam meningkatkan hasil belajar siswa. Bisa dilihat dari nilai rata-rata niai raport, yaitu 76,34 dan setelah belajar menggunakan model pembelajaran penemuan terbimbing (guided discovery) rata-rata nilai meningkat, yaitu 87,59.

Hasil belajar ini tergolong sedang dikarenakan tidak maksimalnya posttest yang menunjukkan bahwa masih ada beberapa siswa yang mendapat nilai post-tes di bawah KKM (Kriteria Ketuntasan Minimal). Hal ini dikarenakan faktor kecerdasan dan minat belajar (Susanto, 2013:12).

Siswa yang mempunyai tingkat kecerdasan yang tinggi akan lebih berhasil dibandingkan dengan siswa dengan kemampuan rendah. Sedangkan siswa dengan tingkat kecerdasan yang normal dapat berhasil dengan baik dalam belajar jika ia belajar dengan baik, artinya belajar dengan menerapkan model pembelajaran yang esisien. Model pembelajaran penemuan terbimbing memberikan dampak yang sangat positif dalam meningkatkan hasil belajar siswa dan bisa digunakan sebagai model pembelajaran yang inovatif karena siswa dituntut aktif selama proses pembelajaran. Keterbatasan waktu dalam penelitian juga mempengaruhi hasil belajar, sebab dalam penerapan model pembelajaran penemuan terbimbing (guided discovery) ini memerlukan waktu agak lama karena untuk menguasai model ini, dibutuhkan tahapan-tahapan yang panjang dan kemampuan memanfaatkan waktu dengan sebaik-baiknya (Illahi, 2012:72). Sehingga dalam penelitian ini, siswa kurang dalam pemberian latihan soal. Faktor kebiasaan siswa yang sering belajar dari apa yang disampaikan oleh guru saja, membuat beberapa siswa sulit menyesuaikan diri dengan model penemuan terbimbing (guided discovery) yang menuntut kemadirian dan aktif dalam pembelajaran (Illahi, 2012:73).

Dari uraian diatas dapat disimpulkan bahwa penerapan model pembelajaran penemuan terbimbing sangat berpengaruh dalam meningkatkan hasil belajar siswa dengan presentase pengaruh $76 \%$.

\section{KESIMPULAN}

Berdasarakan analisis data dan pengujian hipotesis, maka kesimpulan yang dapat dikemukakan dalam penelitian ini, ada pengaruh penerapan model pembelajaran penemuan terbimbing (guided discovery) berbantuan powerpoint terhadap hasil belajar matematika siswa materi trigonometri kelas X MIA MAN Kota Blitar tahun ajaran 2016/2017. Hal ini ditunjukkan dengan $t_{\text {hitung }}>t_{\text {tabel }}$ atau 3,268 $>2.000$ pada taraf signifikansi $5 \%$ dan besar pengaruh penerapan model pembelajaran penemuan terbimbing (guided 
discovery) berbantuan powerpoint terhadap hasil belajar matematika materi trigonometri siswa kelas X MIA MAN Kota Blitar tahun ajaran 2016/2017 yaitu $76 \%$. Menunjukan bahwa besar pengaruh penerapan model ini dalam kategori sedang. Hal ini dikarenakan faktor kecerdasan, minat belajar, dan kebiasaan belajar siswa, serta diperlukan waktu yang cukup dalam penerapan model pembelajaran penemuan terbimbing (guided discovery). Peneliti selanjutnya disarankan untuk memanfaatkan penelitian ini sebagai referensi untuk penelitian yang relevan dengan topik yang sama.

\section{SARAN}

Penelitian ini adalah penelitian awal sehingga masih memerluakan tindak lanjut penelitian yang lebih spesisfik.

\section{DAFTAR RUJUKAN}

Darmawan, Deni. 2014. Metode Penelitian Kuantitatif. Bandung: Remaja Rosdakarya.

Dimyati \& Mudjiono. 2002. Belajar dan Pembelajaran. Jakarta: Rineka Cipta.

Fathani, Abdul Halim. 2012. Matematika Hakikat\&Logika. Yogjakarta: Ar-rruz Media.

Illahi, Mohammad Takdir. 2012. Pembelajaran Discovery Strategy \& Mental Vocational Skil. Jogjakarta: DIVA Press.

Kementerian Pendidikan dan Kebudayaan. 2014. Materi Pelatihan Guru Implementasi Kurikulum 2013 Tahun Ajaran 2014/2015 Mata Pelajaran Matematika SMA/SMK. Jakarta: Badan Pengembangan Sumberdaya Manusia Pendidikan dan Kebudayaan.

Maunah, Binti. 2009. Landasan Pendidikan. Yogjakarta: Teras.

Pidarta, Made. 1997. Landasan Kependidikan Stimulus Ilmu Pendidikan Bercorak Indonesia. Jakarta: PT. Rineka Cipta.

Susanto, Ahmad. 2013. Teori Belajar \& Pemebelajaran di Sekolah Dasar. Jakarta: Prenamedia Group.

Tim penyusun. 2006. Al-Qur'an Al-Karim dan Terjemah Bahasa Indonesia. Kudus: Menara Kudus.

Sugiyono. 2014. Metode Penelitian Kuantitatif Kualitatif dan R\&B. Bandung: CV Alfabeta. 